\title{
The Use of ICT for Tertiary Education in Agriculture and Research in Swaziland: The Case of University of Swaziland (UNISWA) Students
}

\author{
Raufu, M.O. \\ Department of Agricultural Economics and Management, P. O. Luyengo, Luyengo. M205, \\ University of Swaziland, Swaziland.

\section{Masuku, M. B. (Corresponding author)} \\ Department of Agricultural Economics and Management, P. O. Luyengo, Luyengo. M205, \\ University of Swaziland, Swaziland. \\ Tijani, A. A. \\ Department of Agricultural Economics and Management, P. O. Luyengo, Luyengo. M205, \\ University of Swaziland, Swaziland.
}

Received: August 11, 2015 Accepted: August 27, 2015 Published: September 19, 2015

doi:10.5296/jas.v4i1.8142

URL: http://dx.doi.org/10.5296/jas.v4i1.8142

\begin{abstract}
The primary goal of universities is to teach, provide community service, and conduct research. Empirical evidence has shown that innovative research can best be conducted with the aid of ICT. This study therefore, examines factors affecting the use of ICT for tertiary education and research for development among UNISWA students in the Faculty of Agriculture. Stratified random sampling technique was employed to select 113 UNISWA undergraduate and postgraduate students from whom data were obtained using structured questionnaires. Descriptive statistics and Tobit regression model were used to analyse the data.

The results revealed that the radio and television, audio-graphic, email, computer file transfer and multimedia products were the main ICT facilities available. Accessing research and relevant materials online and the use of ICT in improving efficiency of communication among students and lecturers were ranked high by the respondents. Weak wireless services and unemployment were the greatest challenges to the use of ICT facilities by students. Estimated Tobit regression results revealed that availability, accessibility and necessity for ICT facilities significantly influenced their use for learning and research among the undergraduate students while family size, availability, necessity and proficiency were the
\end{abstract}


main factors affecting the use of ICT facilities among the postgraduate students.

In order to encourage the use of ICT among UNISWA students, the study is therefore recommending that (i) The university authorities should make ICT facilities available and accessible to all categories of students, (ii) Departments should incorporate the use of ICT facilities into their curriculum, and (iii) lecturers should give ICT based assignments and use ICT-based teaching methods.

Keywords: Agriculture and Research, ICT, Uniswa, Tertiary Education.

\section{Introduction}

\subsection{Background}

Education is the key to a knowledge economy. To compete effectively in global context, we need an educated and skilled labour force so as to create, share and use knowledge; vibrant system of research and innovation to be able to tap into global knowledge, assimilate and adapt it to the local need. One cannot rule out that knowledge and human capital are increasingly important to successful economies. The skills to productively transform knowledge and information into innovative products and services will largely define successful knowledge economies.

Telecommunication and the Internet are now on the policy "radar screen" in every nation and multinational organisations. Over the past two decades, there has been considerable debate over the extent to which ICT is transforming the economies of the world. Central governments, businesses and international organisations have invested heavily on ICT in anticipation of greater productivity increase and economic transformations. Since knowledge and information have become the most important currency for productivity, competitiveness, an increased wealth and prosperity, nations have and continue to place greater emphasis and priority on human capital development. Learners learn better when learning experience and activities are illustrated with use of ICT materials (Etiubong, 2011). The multi-purpose application of ICT is now regarded as a Utility such as water and electricity and hence has become a major factor in socio-economic development of every nation. ICT now plays a major role in education, learning and research in general, agriculture, health, commerce and even in poverty alleviation by generating or creating new jobs and investment opportunities. It must be stressed that a country without systematic, coherent, innovative and coordinated research culture rarely develops scientifically and economically.

Universities are considered to be the nerve centre of knowledge, innovation and their application to real life situation because of their continued existence is to solve the needs of society. This responsibility could be better served when these institutions of higher learning are current in terms of modern ICT infrastructure. In no doubt Universities are research centres and innovative research can best be conducted by the use of ICT. A relevant education is more important because today's networked world demands a workforce that understands how to use technology as a tool to increase productivity and creativity. If Universities are to play their role and contribute to national development through research and providing innovative education then much effort has to be put in to integrate ICT as pedagogical tool 
and as a component of subject contents.

It is a common practice that students find it difficult to get the right study materials for their respective programmes. Most students complete their chosen programmes without even having the chance to read some of the internationally acclaimed articles and journals. It is also usual to see that most dissertations and thesis by students never see any practical implementation. They are rather kept on the shelves only to collect dust. This can be attributed to the fact that the writing of these thesis and dissertations are not thoroughly researched into due to lack of access to relevant information. With ICT, students during their learning process can access different information and even know the paradigm shift in most literature as this will make them current and know the dynamics of industry. It also offers them to be trained in a way that meets the job market requirements and their final project can be carried out in an innovative manner so that it becomes more practicable than before. The resources used as input in instruction in a systematic and goal directed manner guarantee better qualitative output from school (Etim, 2008).

To keep pace with what is taking place globally, education should be the passport to develop a vibrant economy and ICT is capable to enhance education especially University education so that they will be able to perform their mandated functions to the benefit of mankind. Scientific research in many fields has also been revolutionised by the new possibilities offered by ICTs, from digitisation of information to new recording, simulation and data processing possibilities (Atkins et al., 2003). The education sector has so far been characterised by rather slow progress in terms of innovation development which impact on teaching activities. This article therefore seeks to look at the use of ICT by students for tertiary agricultural education and agricultural research for development in Swaziland.

\subsection{Objective of the Study}

The main objective of the study was to access the use of ICT by post graduate students for tertiary agricultural education and agricultural research for development in Swaziland. The specific objectives were to:

(i) Highlight the source of ICTs available for learning and research to the respondents;

(ii) Determine the level of use of ICT for learning and research by respondents;

(iii) Identify the factors affecting the use of ICT in enhancing education and research productivity; and

(iv) Identify the key challenges and constraints in the use of ICT for learning and research by the respondents.

\section{Methodology}

\subsection{Study Area}

The University of Swaziland (UNISWA) is the only Government University and the only University offering agricultural sciences at the post graduate level in Swaziland. The University of Swaziland, which comprised of three Campuses at Kwaluseni, Luyengo and 
Mbabane, was established in 1982 by an Act of Parliament of the Kingdom of Swaziland with a mandate to teach, conduct research and carry out community service. The University offers Certificate programmes, Diplomas, Bachelor's degrees, Master's degrees and a PhD degree.

\subsection{Sampling Procedure}

The Luyengo campus of the University was purposively selected for the study because it is the only campus that offers degrees in Agricultural Sciences at both the undergraduate and postgraduate levels. Stratified random sampling technique was use. The student population in the faculty of agricultural sciences were divided into undergraduate and postgraduate strata. Out of the 1172 and 86 students that registered between 2013-2014 academic years for undergraduate and postgraduate studies respectively, 10\% (125 respondents) of the total population were sampled. Seventy of the undergraduate students and 55 of the postgraduate students were randomly sampled. Out of the total 125 questionnaires administered, 103 of them, 63 and 40 questionnaires form the undergraduate and postgraduate strata respectively were useful for the analysis.

\subsection{Instrument and Measurement of Variables}

Primary data were collected through the use of questionnaire. The questionnaire composed of 5 sections concerning the demographic features of the students, sources of ICT available for learning and research, which were sub-divided into synchronous and asynchronous media subsections and section for level of use of ICT for learning and research were measured with statements weighed by a 5 points Likert scale. Other two sections also measured by 5 points Likert scales were sections for factors affecting ICT role in enhancing educational and research productivity, comprising of statements on availability, accessibility, necessity and proficiency in use of ICT facilities for learning and research while the last section was on challenges and constraint to the use of ICT.

\subsection{Data Analyses}

\subsubsection{Descriptive Statistics}

Weighted mean score (WMS) was used to rank the available sources of ICT for learning and research, the level of use of the ICT for academic purposes, factors affecting ICT role as well as challenges and constraint to ICT use. The weighted means score was calculated by summing up the responses divided by the number of respondents. Also, standard deviations of the respective items were calculated to determine the overall acceptance of the rank result by the respondents.

\subsubsection{Tobit Regression}

The Tobit regression model was used to analyse the data collected. The dependent variable, the use of ICT was captured through a five point likert scale, and was regressed against some socioeconomic characteristics, which include the gender of the respondents, age, marital status, and family size, average monthly and monthly income/stipends of the students. Other independent variables are availability, accessibility, necessity and proficiency in use of ICT facilities for learning and research.

According to Long (1997), Sigelman (1999) and Green, (2003), the structural equation for the 


\section{Macrothink}

Tobit model is:

$$
\mathrm{y}_{\mathrm{i}}^{*}=\mathrm{X}_{\mathrm{i}} \beta+\varepsilon_{\mathrm{i}}
$$

Where: $\varepsilon_{\mathrm{i}=\mathrm{N}}\left(0, \sigma^{2}\right) . \mathrm{y}_{\mathrm{i}} *$ is a latent variable that is observed for values greater than $\mathrm{T}$ and censored otherwise. The observed y is defined by the following measurement equation:

$$
\begin{gathered}
\mathrm{y}_{\mathrm{i}}=\mathrm{y}_{\mathrm{i}} * \text { if } \mathrm{y}_{\mathrm{i}}{ }^{*}>\mathrm{T} \\
\mathrm{y}_{\mathrm{i}}=\mathrm{T} \text { if } \mathrm{y}_{\mathrm{i}}{ }^{2} \mathrm{~T}
\end{gathered}
$$

It is assumed that $\mathrm{T}=0$ i.e the data are censored at zero. Thus, we have:

$$
\begin{gathered}
\mathrm{y}_{\mathrm{i}}=\mathrm{y}_{\mathrm{i}} * \text { if } \mathrm{y}_{\mathrm{i}}^{*}>0 \\
\mathrm{y}_{\mathrm{i}}=0 \text { if } \mathrm{y}_{\mathrm{i}} * 0
\end{gathered}
$$

\section{Results and Discussion}

Table 1 revealed that radio broadcast and television as well as audio graphic ranked highest among the synchronous media of ICT sources available for both undergraduate and postgraduate students in the University, while use of email, computer file transfer and use of multimedia products ranked highest among the asynchronous media. This could be because these are easily accessible ICT sources. In the case of emails, students also communicate with their lecturers on academic assignments.

Table1. Sources of ICT Available for Learning and Research

\begin{tabular}{llllll}
\hline Sources & $\begin{array}{l}\text { Synchronous Media } \\
\text { Undergraduate } \\
\text { WMS }\end{array}$ & $\begin{array}{l}\text { Postgraduate } \\
\text { WMS }\end{array}$ & Sources & $\begin{array}{l}\text { Asynchronous Media } \\
\text { Undergraduate } \\
\text { WMS }\end{array}$ & $\begin{array}{l}\text { Postgraduate } \\
\text { WMS }\end{array}$ \\
\hline Audio-graphics & $0.16\left(2^{\text {nd }}\right)$ & $0.15\left(2^{\text {nd }}\right)$ & $\begin{array}{l}\text { Audio, video tapes and } \\
\text { CDs }\end{array}$ & $0.14\left(4^{\text {th }}\right)$ & $0.10\left(3^{\text {rd }}\right)$ \\
$\begin{array}{l}\text { Audio } \\
\text { conferencing }\end{array}$ & $0.06\left(4^{\text {th }}\right)$ & $0.13\left(3^{\text {rd }}\right)$ & Email & $0.84\left(1^{\text {st }}\right)$ & $0.95\left(1^{\text {st }}\right)$ \\
$\begin{array}{l}\text { Broadcast } \\
\text { radio \& TV }\end{array}$ & $0.62\left(1^{\text {st }}\right)$ & $0.18\left(1^{\text {st }}\right)$ & Computer file transfer & $0.32\left(2^{\text {nd }}\right)$ & $0.38\left(2^{\text {nd }}\right)$ \\
$\begin{array}{l}\text { Computer } \\
\text { conferencing }\end{array}$ & $0.10\left(3^{\text {rd }}\right)$ & $0.10\left(4^{\text {th }}\right)$ & Virtual conferences & $0.05\left(6^{\text {th }}\right)$ & $0.05\left(5^{\text {th }}\right)$ \\
& & $\begin{array}{l}\text { Multimedia products } \\
\text { Web based learning } \\
\text { format }\end{array}$ & $0.21\left(3^{\text {rd }}\right)$ & $0.13\left(5^{\text {th }}\right)$ & $0.35\left(4^{\text {th }}\right)$ \\
& & & $0.05\left(5^{\text {th }}\right)$ \\
\hline
\end{tabular}

Note: Respondents were asked to select the sources of ICT available to them for learning and research. The figures indicate the mean scores of the selected sources and their rating.

* denotes weighted means

Source: Field Survey 2014

As regard the level of use of ICT in Table 2, accessing research and relevant study materials online was ranked highest among uses of ICT for the undergraduate students, as compared with its use to improve efficiency of communication with colleagues and lecturers was 
ranked highest by the postgraduate students. The fact that response on net to course relevant information and assignments, and communication with colleagues on tutorials and research issues ranked least in level of use of ICT for both the undergraduate and postgraduate students shows that the high ranking of ICT in improving efficiency of communication is not for academic learning and research purposes. Likewise, it can be inferred from the results that though respondents do access research and relevant materials on line but they rarely shared such information among themselves in their online communications.

Table 2. Level of Use of ICT' use for Learning and Research

\begin{tabular}{|c|c|c|c|c|}
\hline Level of Use & $\begin{array}{l}\text { Undergraduate } \\
\text { WMS }\end{array}$ & SD & $\begin{array}{l}\text { Postgraduate } \\
\text { WMS }\end{array}$ & SD \\
\hline Course relevant information online & $3.21\left(4^{\text {th }}\right)$ & 1.42 & $3.33\left(4^{\text {th }}\right)$ & 1.25 \\
\hline $\begin{array}{l}\text { Communicating with colleagues on tutorials and } \\
\text { research }\end{array}$ & $2.92\left(5^{\text {th }}\right)$ & 1.21 & $3.30\left(5^{\text {th }}\right)$ & 1.47 \\
\hline Accessing research and relevant study materials online & $4.19\left(1^{\mathrm{st}}\right)$ & 0.88 & $4.03\left(2^{\text {nd }}\right)$ & 1.19 \\
\hline $\begin{array}{l}\text { Use of ICT for efficiency in communication with } \\
\text { colleagues and lecturers }\end{array}$ & $3.84\left(2^{\text {nd }}\right)$ & 0.94 & $4.18\left(1^{\mathrm{st}}\right)$ & 0.93 \\
\hline $\begin{array}{l}\text { Use of ICT effectively for learning and research } \\
\text { evolved }\end{array}$ & $3.38\left(3^{\text {rd }}\right)$ & 1.18 & $3.68\left(3^{\text {rd }}\right)$ & 1.19 \\
\hline
\end{tabular}

Note: Respondents were asked to rate the level of use of ICT for learning and research on a 5 point Likert scale. The figures indicate the mean scores and their rating.

Source: Field Survey 2014

In terms of availability and accessibility, Table 3 revealed that not having wireless loop in the university to allow internet in the university buildings and classrooms as well as having no access to computers in class were ranked highest respectively by all the respondents. As regards necessity and proficiency in use, problem of not integrating ICT in the curriculum and having no skills to facilitate use of available packages for learning and research respectively were ranked highest by the postgraduate students while not being referred to net for further study/research and lack of pre-requisite knowledge for effective use of ICT were the highest factors in terms of necessity and proficiency among the undergraduate respondents. Their standard deviation of less than 2 indicated that many of the students at both level agreed to the identified factors as highly affecting the role of ICT in enhancing education and research productivity in agriculture.

Table3. Factors Affecting ICT Role in Enhancing Education and Research Productivity

\begin{tabular}{llclc}
\hline Factors Affecting ICT Role & $\begin{array}{l}\text { Undergraduate } \\
\text { WMS }\end{array}$ & SD & $\begin{array}{l}\text { Postgraduate } \\
\text { WMS }\end{array}$ & SD \\
\hline $\begin{array}{l}\text { Availability } \\
\text { *No wireless loop in the University to allow internet } \\
\text { in University buildings and classrooms }\end{array}$ & $3.57\left(1^{\text {st }}\right)$ & 1.51 & $3.23\left(1^{\text {st }}\right)$ & 1.52 \\
& & & &
\end{tabular}


*The University ICT centre do not have enough ICT $3.46\left(2^{\text {nd }}\right)$

$\begin{array}{ll}1.32 & 2.68\left(2^{\text {nd }}\right)\end{array}$

1.36

facilities to enhance tertiary agricultural education

and research for development

*Multimedia are not always available in classroom

for presentations

$$
2.83\left(3^{\text {rd }}\right) \quad 1.16 \quad 2.63\left(3^{\text {rd }}\right) \quad 1.37
$$

\section{Accessibility}

*No access to computers in class

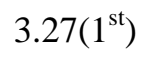

$1.54 \quad 3.70\left(1^{\mathrm{st}}\right)$

Necessity

*Lecturers do not refer students to net for further

$2.24\left(1^{\mathrm{st}}\right)$

$1.36 \quad 1.93\left(2^{\mathrm{nd}}\right)$

study/research

*ICT is not integrated in the curriculum

$2.40\left(2^{\text {nd }}\right)$

$1.042 .98\left(1^{\text {st }}\right)$

Proficiency

*No required skills to facilitate use of available

$2.71\left(2^{\text {nd }}\right)$

$1.113 .63\left(1^{\mathrm{st}}\right)$

packages for learning and research

*Required knowledge is not gotten from the $2.40\left(3^{\text {rd }}\right)$

$0.962 .10\left(3^{\text {rd }}\right)$

educational administrators/lecturers

*Have no enough background or pre-requisite

knowledge for effective use of ICT for tertiary agricultural education and research for development

Note: Respondents were asked to rate factors affecting ICT role in enhancing education and research productivity vis-a-vis availability, accessibility, necessity and proficiency in use on a 5 point Likert scale. The figures indicate the mean scores and their overall rating.

Source: Field Survey 2014

Table 4. shows that students at both levels see weak wireless service in the library and the classrooms as well as working and learning that reduce the chance of learning and research through ICT as the greatest challenges and constraints to the use of ICT.

Table4. Challenges and Constraints to the Use of ICT

\begin{tabular}{|c|c|c|c|c|}
\hline Challenges and Constraints & $\begin{array}{l}\text { Undergraduate } \\
\text { WMS }\end{array}$ & SD & $\begin{array}{l}\text { Postgraduate } \\
\text { WMS }\end{array}$ & SD \\
\hline High charged fees for the use of ICT & $2.67\left(4^{\text {th }}\right)$ & 1.28 & $1.98\left(5^{\text {th }}\right)$ & 1.17 \\
\hline Other office services are not available & $2.40\left(5^{\text {th }}\right)$ & 1.21 & $2.68\left(4^{\text {th }}\right)$ & 1.69 \\
\hline $\begin{array}{l}\text { Working and learning reduce the chance of learning } \\
\text { and research through ICT }\end{array}$ & $3.40\left(2^{\text {nd }}\right)$ & 1.14 & $3.30\left(2^{\text {nd }}\right)$ & 1.47 \\
\hline $\begin{array}{l}\text { Space constraint of face-to-face learning experience } \\
\text { affect learning and research for development }\end{array}$ & $3.16\left(3^{\text {rd }}\right)$ & 0.81 & $2.95\left(3^{\text {rd }}\right)$ & 1.01 \\
\hline $\begin{array}{l}\text { The University internet wireless service is weak in the } \\
\text { library and the classrooms }\end{array}$ & $4.20\left(1^{\mathrm{st}}\right)$ & 1.08 & $4.00\left(1^{\mathrm{st}}\right)$ & 1.36 \\
\hline
\end{tabular}

Note: Respondents were asked to rate the challenges and constraint to the use of ICT on a 5 point Likert scale. The figures indicate the mean scores and their rating. 
Source: Field Survey 2014

Table 5 revealed that for the undergraduate students, availability, accessibility and necessity significantly affect the level of use of ICT for learning and research in the institution. Both accessibility and necessity for ICT facilities negatively influenced the probability of use of ICT for learning and research at 5\% and $1 \%$ significant level respectively. This implies that with increase in access there is a probability of $14.1 \%$ decrease in use of ICT facilities by the undergraduate students as well as $27.8 \%$ probability of decrease in use for learning and research with increase necessity. However, the availability of these facilities has a potential of increasing their use by $20 \%$ and it is significant at $10 \%$ level. This buttress the fact that students tend to misuse the technology for leisure time activities and have less time to learn and study. Yousef and Dahmani (2008) described online gaming, use of face book, chat rooms, and other communication channels as perceived drawbacks of ICT use in learning and research, because, students easily switch to these sites at the expense of their study. Internet access at home, for instance, may be a distraction because of chat rooms and online games, reducing the time spent in doing assignments and learning (Kulik,1994). Therefore, the impact of availability of ICT on student learning strongly depends on its specific uses.

Table 5. Tobit Analysis of Factors Affecting Use of ICT for Learning and Research Among the Undergraduate Students

\begin{tabular}{lllll}
\hline Variable & Coefficient & Standard Error & t-value & p-value \\
\hline Constant & 0.9946 & 0.1833 & 5.425 & 0.0000 \\
Sex & $0.3636 \mathrm{E}-04$ & $0.3848 \mathrm{E}-01$ & 0.001 & 0.9992 \\
Age & $-0.4612 \mathrm{E}-02$ & $0.5820 \mathrm{E}-02$ & -0.792 & 0.4281 \\
MS & $-0.4474 \mathrm{E}-01$ & $0.7303 \mathrm{E}-01$ & -0.613 & 0.5401 \\
Fmlsz & $-0.2628 \mathrm{E}-02$ & $0.6650 \mathrm{E}-02$ & -0.395 & 0.6927 \\
Amt-Spnt & $-0.4025 \mathrm{E}-03$ & $0.1452 \mathrm{E}-02$ & -0.277 & 0.7817 \\
Ravail & $0.2004^{*}$ & 0.1034 & 1.938 & 0.0526 \\
Raccess & $-0.1405^{* *}$ & $0.6355 \mathrm{E}-01$ & -2.211 & 0.0270 \\
Rproficn & $-0.5484 \mathrm{E}-01$ & 0.1017 & -0.539 & 0.5898 \\
Rnecess & $-0.2780^{* * *}$ & $0.9017 \mathrm{E}-01$ & -3.083 & 0.0021 \\
\hline
\end{tabular}

Source: Field Survey 2014

$*, * *$, and $* * *$ indicate significance at $10 \%, 5 \%$, and $1 \%$

From Table 6, the postgraduate students' family size and the availability of ICT facilities positively influenced their use at $5 \%$ and $1 \%$ significant level respectively, while proficiency in use and necessity of use negatively affect their use and are both significant at $1 \%$ level. This likewise implies that increase in the students' proficiency and necessity to use ICT facilities does not necessarily result to the use of these facilities for research purposes but rather for other uses. This confirmed Ma, Andersson, and Streith (2005) that the student teachers' perceived ease of use had only an indirect significant effect on intention to use. 
Table 6. Tobit Analysis of Factors Affecting Use of ICT for Learning and Research Among the Postgraduate Students

\begin{tabular}{lllll}
\hline Variable & Coefficient & Standard Error & t-value & p-value \\
\hline Constant & 0.6834 & 0.2161 & 3.163 & 0.0016 \\
Sex & $0.2192 \mathrm{E}-01$ & $0.3986 \mathrm{E}-01$ & 0.550 & 0.5824 \\
Age & $-0.6260 \mathrm{E}-02$ & $0.5295 \mathrm{E}-02$ & -1.182 & 0.2371 \\
Job & $0.5967 \mathrm{E}-01$ & $0.5016 \mathrm{E}-01$ & -1.189 & 0.2343 \\
MS & $-0.2825 \mathrm{E}-02$ & $0.4666 \mathrm{E}-01$ & -0.061 & 0.9517 \\
Fmlsz & $0.3291 \mathrm{E}-01 * *$ & $0.1155 \mathrm{E}-01$ & 2.117 & 0.0343 \\
Yrdeg Compl & $0.4734 \mathrm{E}-02$ & $0.8278 \mathrm{E}-02$ & 0.572 & 0.5674 \\
Amt-Spnt & $0.4755 \mathrm{E}-04$ & $0.3443 \mathrm{E}-04$ & 1.381 & 0.1672 \\
Ravail & $0.3384^{* * *}$ & 0.1168 & 2.898 & 0.0038 \\
Raccess & $-0.4571 \mathrm{E}-01$ & $0.7596 \mathrm{E}-01$ & -0.602 & 0.5473 \\
Rprofic & $-0.3086^{* * *}$ & 0.1149 & -2.686 & 0.0072 \\
Rnecess & $-0.3867 * * *$ & 0.1172 & -3.299 & 0.0010 \\
\hline
\end{tabular}

Source: Field Survey 2014

$*, * *$, and $* * *$ indicate significance at $10 \%, 5 \%$, and $1 \%$

Analysis of the pooled data in Table 7 revealed that age, being employed, monthly expenses on the programme, and necessity are the factors that affect use of ICT and they all have a negative relationship with the use of ICT at $1 \%$ significant level except age that is significant at $10 \%$. They all reduce the probability of ICT use by about $2 \%, 48.6 \%, 1 \%$ and $42.2 \%$ respectively among all the respondents.

Table 7. Tobit Analysis of Factors Affecting the Use of ICT for Learning and Research for the Pooled Data

\begin{tabular}{lllll}
\hline Variable & Coefficient & Standard Error & t-value & p-value \\
\hline Constant & 2.013 & 2.784 & 7.231 & 0.0000 \\
Sex & $0.4464 \mathrm{E}-02$ & $0.5871 \mathrm{E}-01$ & 0.076 & 0.9394 \\
Age & $-0.1698 \mathrm{E}-01^{*}$ & $0.9022 \mathrm{E}-02$ & -1.882 & 0.0598 \\
Job & $-0.4865^{* * *}$ & 0.1148 & -4.239 & 0.0000 \\
MS & $-0.9006 \mathrm{E}-01$ & $0.9355 \mathrm{E}-01$ & -0.963 & 0.3357 \\
Fmlsz & $0.1205 \mathrm{E}-01$ & $0.1053 \mathrm{E}-01$ & 1.144 & 0.2526 \\
Amt-Spnt & $-0.9330 \mathrm{E}-03^{* * *}$ & $0.1767 \mathrm{E}-03$ & -5.281 & 0.0000 \\
Ravail & $0.8032 \mathrm{E}-01$ & 0.1581 & 0.508 & 0.6118 \\
Raccess & -0.1408 & $0.9593 \mathrm{E}-01$ & -1.468 & 0.1421 \\
Rprofic & 0.1941 & 0.1509 & 1.286 & 0.1983 \\
Rnecess & $-0.4223^{* * *}$ & 0.1435 & -2.944 & 0.0032 \\
\hline
\end{tabular}

Source: Field Survey 2014

$*, * *$, and $* * *$ indicate significance at $10 \%, 5 \%$, and $1 \%$

\section{Conclusion and Recommendations}

\subsection{Conclusion}

The results revealed that the radio and television, audio-graphic, email, computer file transfer 
and multimedia products were the main ICT facilities available online and the use of ICT in improving efficiency of communication among students and lecturers were ranked high by the respondents. Weak wireless services and employment were greatest challenges to the use of ICT facilities by the students. The estimated Tobit regression results revealed that availability, accessibility and necessity for ICT facilities significantly influenced their use for learning and research among the undergraduate students while family size, availability, necessity and proficiency were main factors affecting the use of ICT facilities among the postgraduate students.

\subsection{Recommendation}

The study therefore recommended that students should be taught to use ICT not only for social interactions, but also for educational and research purposes by incorporating the use of ICT facilities into their curriculum. They should be trained on the use of both synchronous and asynchronous media as well as relevant packages for research and development. The university should make ICT facilities available and accessible to all categories of students. The like of MTN cyber zone provided for the institution by the communication service provider, MTN, should be upgraded and updated so that a ratio one to one student-computer ratio will be possible. Likewise, similar Non-governmental organizations (NGOs) should be approached on the provision of ICT centre for postgraduate students to enhance educational and research productivity.

\section{Reference}

Atkins, D. E., Droegemeier, K. K., Feldman, S. I., Garcia-Molina, H., Klein, M. L., Messerschmitt, D. G., Messina, P., Ostriker, J. P., \& Wright, M. H. (2003). Final Report of the NSF Blue Ribbon Advisory Panel on Cyber infrastructure, available at http://www.cise.nsf.gov/sci/reports/toc.cfm.

Etim, P. J. (2008). Effect of flexible learning in academic achievement of science education students in the university of uyo, Nigeria. proceedings of Nigeria association for educational media and technology.

Etiubong, L. U. (2011). Engaging technological resources to enhance students' performance in chemistry. Nigeria Journal of Education, 4(4), 230-240.

Green, W. H. (2003). Econometric Analysis. 5th edition. Upper Saddle River, N. J., Prentice Hall.

Kulik, J. A. (1994). Meta-analytic studies of findings on computer-based instruction. In J.E.L.Baker and H. F. O' Neil (Ed.), Technology assessment in education and training. Hillsdale, N. J: Lawrence Erlbaum.

Long, J. S. (1997). Regression models for categorical and limited dependent variables. London, Sage Publications.

Ma, W. W., Andersson, R., \& Streith, K.-O. (2005). Examining user acceptance of computer technology: An empirical study of student teachers. Journal of Computer Assisted Learning, 21, 387-395.

Sigelman, L., \& Langche, Z. (1999). Analysing Censored and Sample-Selected Data with Tobit and Heckit Models. Political Analysis, 8, 167-182. 


\section{Macrothink}

Journal of Agricultural Studies

ISSN 2166-0379 2016, Vol. 4, No. 1

Yousef, A. B., \& Dahamini, M. (2008). The economics of E- Learning: The impact of ICT on student performance in higher education: direct effects, indirect effects and organizational change, (http://rusc.uoc.edu).

\section{Copyright Disclaimer}

Copyright for this article is retained by the author(s), with first publication rights granted to the journal.

This is an open-access article distributed under the terms and conditions of the Creative Commons Attribution license (http://creativecommons.org/licenses/by/3.0/). 